\title{
Knee Pads Do Not Affect Physical Performance in Young Female Volleyball Players
}

\author{
Anja Lazić ${ }^{1}$, Milovan Bratić ${ }^{1}$, Stevan Stamenković $^{1}$, Slobodan Andrašić ${ }^{2}$, Nenad Stojiljković ${ }^{1}$ (i) \\ and Nebojša Trajković ${ }^{1, *(1)}$ \\ 1 Faculty of Sport and Physical Education, University of Niš, 18000 Niš, Serbia; anja.lazic96@hotmail.com (A.L.); \\ bratic@fsfv.ni.ac.rs (M.B.); sstamenkovic.fsfv@gmail.com (S.S.); snesadif@yahoo.com (N.S.) \\ 2 Faculty of Economics, University of Novi Sad, 24000 Subotica, Serbia; slobodan.andrasic@ef.uns.ac.rs \\ * Correspondence: nele_trajce@yahoo.com; Tel.: +381-652-070-462
}

\section{check for}

updates

Citation: Lazić, A.; Bratić, M.; Stamenković, S.; Andrašić, S.; Stojiljković, N.; Trajković, N. Knee Pads Do Not Affect Physical Performance in Young Female Volleyball Players. Children 2021, 8, 748. https://doi.org/10.3390/ children 8090748

Academic Editors: Filipe

Manuel Clemente and Ana Filipa Silva

Received: 3 August 2021

Accepted: 25 August 2021

Published: 30 August 2021

Publisher's Note: MDPI stays neutra with regard to jurisdictional claims in published maps and institutional affiliations.

Copyright: (c) 2021 by the authors. Licensee MDPI, Basel, Switzerland. This article is an open access article distributed under the terms and conditions of the Creative Commons Attribution (CC BY) license (https:// creativecommons.org/licenses/by/ $4.0 /)$.
Abstract: Knee pads have become increasingly popular among volleyball players. Given the fact high-intensity activities that are crucial to successfully playing this sport lead to an increased risk of a knee injury, the primary use of knee pads is to prevent potential injury. However, no research has been carried out to explain the effects of knee pads on the most important physical abilities in volleyball players, thus directly affecting performance. This study was undertaken to determine the effects of knee pads on the explosive power of the lower extremities, linear speed, and agility in young female volleyball players. In two separated sessions, 84 female volleyball players (age: $14.83 \pm 0.72$ years; height: $163.19 \pm 8.38 \mathrm{~cm}$; body mass: $53.64 \pm 10.42 \mathrm{~kg}$; VE: $5.30 \pm 3.39$ years) completed squat jumps (SJ), countermovement jumps (CMJ) with and without arm swing, linear sprints at 5-m and 10-m, modified $t$-test, and 5-10-5 shuttle test. Data analyses included descriptive statistics, paired sample $T$-tests and use of effect size (ES). There was no statistical difference between the two conditions for SJ ( $p=0.156$; ES =0.18), CMJ ( $p=0.817$; ES =0.03), CMJ with arm swing $(p=0.194 ; \mathrm{ES}=0.14)$, linear sprint at $5 \mathrm{~m}(p=0.789 ; \mathrm{ES}=0.03)$ and $10 \mathrm{~m}(p=0.907 ; \mathrm{ES}=-0.01)$, modified $t$-test $(p=0.284 ; \mathrm{ES}=0.13)$, and 5-10-5 shuttle test $(p=0.144 ; \mathrm{ES}=0.19)$. Wearing knee pads has neither an inhibitory nor positive effects on explosive power of the lower extremities, linear speed, and agility in young female volleyball players.

Keywords: jumping performance; speed; agility; team sport

\section{Introduction}

During a volleyball match, $80 \%$ of the points obtained are the result of high-intensity activities performed with maximal and submaximal intensity [1]. On average, volleyball players perform 250-300 high-intensity activities [2], over 100 jumps [3], and a large number of sprints up to $10 \mathrm{~m} \mathrm{[3],} \mathrm{which} \mathrm{together} \mathrm{with} \mathrm{technical} \mathrm{and} \mathrm{tactical} \mathrm{elements} \mathrm{[4]} \mathrm{define}$ volleyball as an intermittent and complex team sport, where high-intensity movements are followed by a short period of low-intensity activities [5,6]. Also, frequent changes in the rules of the game [6], the popularization and increasing in professionalism [7], specific dimensions of the court [8], and thus the high demands of the game [9], have led to a high level of physical fitness-primarily explosive power of the upper and lower extremities, speed, and agility represented as a crucial factor for successfully playing this sport at elite level [10-12]. Specifically, explosive power is manifested through a wide range of volleyball elements-ball hitting, jumps, and blocks [4,7], while speed and agility are manifested through sudden changes of movement direction [10-12], where maximal speed rarely develops [13], and movements are closely related to the unpredictable nature of actions [14]. The frequency and importance of these abilities lead to the fact that volleyball players are more prone to knee injuries, particularly to a ruptured anterior cruciate ligament $[15,16]$. Landings are often performed on one or both legs [17] and are 
associated with multiplanar cutting and pivoting movements that may increase stress load on the knee joint [14], especially in female volleyball players [18].

Prevention of potential volleyball injuries has received a lot of research attention [19]. Knee pads have become increasingly popular in volleyball players, being designed to give dynamic stability and prevent potential injury [20]. While there is no research on knee pads, knee braces have been extensively researched in rehabilitation and prevention of knee injuries in athletes [20-29]. The purpose of these braces is to effectively reduce knee valgus during lateral forces [30] without limitations in athletic performance. However, available studies addressing knee braces in injury prevention show contradictory results. While some studies have reported positive effects of knee braces in injury prevention [23,24], others have shown no effect [27-29], and Deppen with colleagues [25] together with Grace and colleagues [26], have even reported an increase in knee injury rates. Because of that, the role of knee braces is still poorly understood. This has an additional impact on athletes, who mostly avoid wearing this type of brace because of the potential negative impact on athletic performance [20,31-33]. Within this area of investigation, a number of studies [30,34-41] have reported conflicting results. Improvements in physical performance have been shown in $[34,35]$ in contrast to those who have shown negative effects $[36,40]$ and no effects [30,39-41] of wearing knee braces on physical performance.

However, most of these studies have utilized healthy or injured athletes, recreational athletes or non-athletes, this resulting in that the performed tests do not show the real nature of a specific competitive sport, especially in volleyball where knee pads are worn constantly and where the use of knee pads may result in decreased performance when participants become accustomed to wearing them. Since knee pads are worn by many volleyball players, it is critical to determine if wearing them significantly affects physical performance. The aim of this study was to determine the effects of knee pads on the explosive power of the lower extremities, linear speed, and agility in young female volleyball players.

\section{Materials and Methods}

\subsection{Participants}

A total of 84 young female volleyball players (age: $14.83 \pm 0.72$ years; height: $163.19 \pm 8.38 \mathrm{~cm}$; body mass: $53.64 \pm 10.42 \mathrm{~kg}$ ) volunteered to participate in the study. All participants were members of the same volleyball club. Participants had $5.30 \pm 3.39$ years of volleyball experience. Participants were free of injuries and medical conditions that might have placed them at risk for safe participation in the study. All participants were informed of the study procedures and provided written informed consent prior to participation, including parental consent for participants under 18 years of age.

\subsection{Procedures}

A repeated-measures study design was used in this study. Each participant completed two experimental trials on an indoor, hardwood volleyball court under similar environmental conditions at the same time of the day (19:00-21:00). Experimental trials were separated by $72 \mathrm{~h}$. The first trial session involved testing without knee pads. After $72 \mathrm{~h}$ the same procedure was repeated with the use of knee pads. Before both experimental trials, participants performed a standardized warm-up, consisting of moderate-intensity jogging (5-10 $\mathrm{min}$ ) and static and dynamic stretching (5 min) without knee pads during the first session and with knee pads during the second session. The study was conducted in accordance with the Novi Sad University Human Research Ethics Committee guidelines (ethical approval number: 20/2019; approval date of Ethic Committee approval: 20 October 2020).

2.3. Tests

\subsubsection{Vertical Jump Assessment}

Three tests were used to assess the explosive power of the lower extremities: squat jump (SJ), countermovement jump (CMJ), and countermovement jump with arm swing. Participants performed each jump three times. The break between each repetition of the 
jump was $30 \mathrm{~s}$, while the break between series of new jumps was $5 \mathrm{~min}$. Each participant was instructed to jump naturally and as high as they could, performing all jumps with maximal effort. The highest value of the vertical jump height for all three groups of tests was included in the statistical analysis. Optojump (Optojump, Microgate, Bolzano, Italy) was used to estimate the vertical height of the jump, and its validity and reliability were confirmed, considering low coefficients of variation $(2.7 \%)$ and low random errors $(+2.81 \mathrm{~cm})$ [42]. The participants performed three jumps with arm swing and were instructed to jump naturally and as high as they could, performing all jumps with maximal effort.

\subsubsection{Linear Speed Assessment}

The linear sprinting speed was evaluated at $5 \mathrm{~m}$ and $10 \mathrm{~m}$ using a photocell system (Witty, System, Microgate, Bolzano, Italy). Each participant repeated the test three times with at least $2 \mathrm{~min}$ of rest between trials, and the fastest time was recorded for further statistical analysis. Photocells were placed at a distance of $5 \mathrm{~m}$ and $10 \mathrm{~m}$ from the starting line. Photocells were placed $0.4 \mathrm{~m}$ above the ground with an accuracy of $0.001 \mathrm{~m} / \mathrm{s}$ to minimize the effect of hand swing when passing through the gate [43].

\subsubsection{Agility Assessment}

Agility assessment was performed using two tests-modified $t$-test and 5-10-5 shuttle test. Participants repeated each of test three times, with a break of $30 \mathrm{~s}$ between attempts and a 5 min break between the tests. The fastest time on agility tests was taken in further statistical analysis of the data. Modified $t$-test procedures were in accordance with Sassi et al. [44]. Upon command of the examiner, the participant sprinted towards the cone $\mathrm{B}$ set at the distance of $5 \mathrm{~m}$ and touched the base of the cone with the right hand. Then, they turned left and shuffled sideways to cone C $(2.5 \mathrm{~m})$, touching the base with the left hand. Then, shuffling sideways to the cone $\mathrm{D}(5 \mathrm{~m})$, touching its base with the right hand, followed up by shuffle to the left to the cone $B(5 \mathrm{~m})$, touching its base with the left hand and running back to the cone $\mathrm{A}(5 \mathrm{~m})$. The time was stopped when the start with photocell was passed by. Trials were deemed unsuccessful if participants failed to touch a designated cone, crossed their legs while shuffling, or were unable to face forward at all times. The 5-10-5 shuttle test was performed according to National Strength and Conditioning Association (NSCA) protocols [45] and measured with photo cell timing gates (Brower Timing Systems, Draper, UT). Briefly, three cones were placed five yards apart on the surface of the volleyball court. The each participant started in a three point stance and upon command sprinted right and touched the line at the first cone with his hand, the subject then turned 180 degrees and sprinted to touch the left cone line with his hand, then turned 180 degrees to sprint back to the start. The 5-10-5 shuttle run has been shown to be a reliable (ICC $=0.90, \mathrm{SEM}=0.12$ ) test of change of direction [46].

\subsection{Statistical Analysis}

Statistical analysis was performed by the IBM SPSS statistics program (version 26.0; Inc., Chicago, IL, USA). Descriptive statistics were used to obtain basic information about the participants. The normality of data distribution was determined by KolmogorovSmirnov test for all dependent variables, while to determine the differences in explosive power of the lower extremities, linear speed and agility between the two conditions, the paired sample $T$-tests were used. The magnitude of difference between the two conditions was measured with effect size (ES) analyses and interpreted as: trivial $\leq 0.20$; small $=0.2-0.49 ;$ moderate $=0.50-0.79 ;$ large $\geq 0.80$ [47]. Data are presented as mean \pm standard deviation (SD) and statistical significance level was set at $p<0.05$

\section{Results}

Descriptive statistics of participants are shown in Table 1 while means and standard deviations for each dependent variable in the non-braced and braced condition are shown in Table 2. ES (effect size) comparisons between the conditions are presented in Table 2. 
Table 1. Descriptive statistics of participants.

\begin{tabular}{ccccc}
\hline $\begin{array}{c}\text { Outcome } \\
\text { Measure (Unit) }\end{array}$ & N & Min & Max & Mean \pm SD \\
\hline Age (year) & 84 & 12 & 20 & $14.83 \pm 0.72$ \\
VE (year) & 84 & 1 & 15 & $5.30 \pm 3.39$ \\
Height (cm) & 84 & 147.0 & 179.5 & $163.19 \pm 8.38$ \\
Body mass (kg) & 84 & 35.0 & 85.7 & $53.64 \pm 10.42$ \\
\hline
\end{tabular}

$\mathrm{VE}$-volleyball experience; $\mathrm{N}-$ a total number of participants; SD—standard deviation.

Table 2. Differences and effect size values between the conditions.

\begin{tabular}{|c|c|c|c|c|}
\hline \multirow{2}{*}{ Outcome Measure } & \multicolumn{2}{|c|}{ Condition } & \multirow[t]{2}{*}{$p$ Value } & \multirow[t]{2}{*}{ ES } \\
\hline & Without Knee Pads & With Knee Pads & & \\
\hline \multicolumn{5}{|l|}{ Vertical jump height } \\
\hline $\mathrm{SJ}(\mathrm{cm})$ & $23.55 \pm 5.03$ & $24.47 \pm 5.06$ & 0.156 & 0.18-trivial \\
\hline CMJ without arm swing $(\mathrm{cm})$ & $24.46 \pm 5.46$ & $24.61 \pm 5.56$ & 0.817 & 0.03 -trivial \\
\hline CMJ with arm swing (cm) & $29.91 \pm 6.40$ & $30.90 \pm 7.30$ & 0.194 & 0.14 -trivial \\
\hline \multicolumn{5}{|l|}{ Linear sprint speed } \\
\hline $5 \mathrm{~m}$-sprint (s) & $1.25 \pm 0.15$ & $1.25 \pm 0.12$ & 0.789 & 0.03-trivial \\
\hline $10 \mathrm{~m}-$ sprint $(\mathrm{s})$ & $2.18 \pm 0.18$ & $2.17 \pm 0.17$ & 0.907 & $-0.01-$ trivial \\
\hline \multicolumn{5}{|l|}{ Agility } \\
\hline modified $t$-test (s) & $7.40 \pm 0.58$ & $7.48 \pm 0.64$ & 0.284 & 0.13 -trivial \\
\hline $5-10-5$ test $(\mathrm{s})$ & $5.96 \pm 0.35$ & $6.03 \pm 0.40$ & 0.144 & 0.19 -trivial \\
\hline
\end{tabular}

SJ—squat jump; CMJ—counter movement jump; $p$ value- significant difference, $p=0.05$; ES—effect size.

Table 1 shows that the mean age of the 84 female volleyball players was $14.83 \pm 0.72$ years (range: $12-20$ years), with a mean height of $163.19 \pm 8.38 \mathrm{~cm}$ (range: $147.0-179.5 \mathrm{~cm}$ ) and mean weight $53.64 \pm 10.42 \mathrm{~kg}$ (range: $35.0-85.7 \mathrm{~kg}$ ); mean volleyball experience was $5.30 \pm 3.39$ years (range: $1-15$ years).

The Kolmogorov-Smirnov tests showed that data were normally distributed and homogeneity of variance was confirmed using the Levene's test. Paired sample T-tests were used to determine potential differences between braced and non-braced conditions in height of vertical jumping, linear sprinting speed, and agility. Table 2 shows non-significant differences found for any variable between the two conditions. Wearing knee pads resulted in a trivial, non-significant increase in SJ $(E S=0.18), C M J(E S=0.03)$ and non-significant increase in CMJ with arm swing $(E S=0.14)$; trivial, non-significant reduction in the time required to perform linear sprint at $5 \mathrm{~m}(\mathrm{ES}=0.03)$; and trivial, non-significant reduction in the time required to perform linear sprint at $10 \mathrm{~m}(\mathrm{ES}=-0.01)$. Finally, wearing knee pads resulted in trivial, non-significant increase in the time required to perform modified $t$-test $(\mathrm{ES}=0.13)$ and 5-10-5 shuttle test $(\mathrm{ES}=0.19)$.

\section{Discussion}

The aim of this study was to determine the effects of wearing knee pads on young female volleyball players, on the explosive power of the lower extremities, linear speed, and agility. The results showed that there were no statistically significant differences between the two conditions and that wearing knee pads did not improve, but also did not inhibit specific volleyball performance.

Although a considerable body of research has been done on the effects of knee bracing in injured athletes [35,48,49] and non-athletes [30,39], less attention has been paid to the population of interest $[41,50,51]$. Past studies in non-injured populations have yielded some important insights into the effects of wearing a knee brace on height during vertical jumping $[30,39,41,50,51]$. Taken altogether, the data presented here provide evidence that the braces do not affect vertical jump height. Studies of Batlaci et al. [30] and Veldhuizen et al. [39] investigated vertical jump height in young, uninjured participants and found no 
statistically significant differences between braced and non - braced conditions. However, due to the sample of participants $[30,39]$ as well as the selection of the tests for assessing the explosive power of the lower extremities [30], these findings do not aplly to athletes. Substantially, studies involving athletes [41,50] have not defined definite differences between the two conditions. Rishiraj and colleagues [50] conducted five testing sessions in each condition. Statistically significant differences were noticeable at the initial testing session, but at the final testing session, no difference was found in the vertical jump. Mortaza and colleagues [41] included 31 male athletes in one testing session and found no effect of bracing on vertical jump. While we could not find initial significant effects of bracing in volleyball players, in braced and non-braced condition, Rishiraj et al. [50] and Veldhuizen et al. [39] found initial, acute decrease in vertical jump height. A possible explanation could be given by Aktas and Baltaci [51], who emphasize that the external load exerted by the knee braces can apply excessive pressure to the skin and change the physiology by inhibiting the mechanoreceptors of the knee, which may results in negative acute effects of knee bracing. However, there is no reliable evidence that this decrease is due to wearing knee braces, given that after the period of $14 \mathrm{~h} \mathrm{[50]} \mathrm{and} 28$ days [39], there were no statistically significant differences between braced and non-braced conditions. Also, in this study, the period between the trials was $72 \mathrm{~h}$, it should be added that volleyball players use knee pads more and longer than other athletes, so we should not rule out potential earlier adaptation to wearing a pad as a mediator of non-significant differences.

In contrast to the findings of this study, where sprint performance at $5 \mathrm{~m}$ and $10 \mathrm{~m}$ did not differ between braced and non-braced conditions, previous studies [39,50,52-54] have demonstrated that knee braces inhibit running velocity at short distances. These findings are less surprising if we consider the sample of participants. Veldhuzen et al. [39] included eight healthy volunteers and found that sprinting time during $60 \mathrm{~m}$ Dash test was $4 \%$ longer than in non-braced volunteers. Similarly, Rishiraj et al. [50] reported longer time at $10 \mathrm{~m}$ sprint. However, both studies concluded that after getting accustomed to knee brace, after 4 weeks [39] and $14 \mathrm{~h}$ [50], results came back to baseline compared to unbraced condition. In other studies, participants were rugby players [52], young male athletes [50], and young college athletes in unspecified sports [53]. These findings are not generalizable to volleyball players. A possible reason for this discrepancy might be that sprint performance depends on the type of knee brace. In a study conducted by Green and colleagues [55], the effects of six different knee braces on speed and agility were analyzed. Four out of six braces negatively affected athletic performane. This finding is congruent with the work of Albright et al. [54], which showed that longer time required to complete sprint tests depends on a variety of factors, among which the most important are the weight and design of the knee brace. The weight of the knee brace leads to altered activity of the knee extensors and hip flexors [53], which are the most active muscles while jogging, running or sprinting [56]. However, a more relevant study to explain the results obtained is a study of Stephens [57] who reported that knee bracing had no effect on sprint speed. This is a statement with a strong background, because basketball and volleyball have many more similarities as team, indoor sports with a specific manifestation of physical fitness [58] than other sports presented in the disscusion.

Wearing a knee brace may negatively affect agility and athletic performance [59], taking into account the fact that agility is a crucial ability in many sports. However, there was no statistical difference between the two conditions in time required to complete the agility tests with or without knee pads. A limited number of studies $[55,59,60]$ have addressed the fact that agility maneuvers are not affected by knee bracing. However, while the former study of Rishiraj et al. [60] showed no differences between the two conditions in agility slalom test and the figure-of-eight test, the latter study, which included 27 young male athletes [50], resulted in initially longer time required to complete agility test in braced-group, but after $14 \mathrm{~h}$, results came back to baseline as in unbraced condition. They attributed decrease in performance to the adaptation to wearing a knee brace. The weakness of this research is that they examined agility without cutting movements, in regard to a 
straight line. Similarly, Green et al. [55] showed that agility performance depends on the type of knee brace, where significant differences were found only with one of six braces.

These findings are less surprising if we consider that the volleyball players were wellrested during the assessment, without the previous high-intensity activities, so it would be more relevant to determine the impact of knee pads on vertical jump, speed, and agility in condition of acute fatigue, similar to that during a volleyball match. A possible reason for this discrepancy might be that non-significant differences are probably a consequence of the weight and design of volleyball knee pads, which are lighter, with different designs, in relation to the majority of knee braces presented in the discussion. At present our dataset is limited to studies which do not address knee pads or a specific volleyball population. Therefore, these findings are not sufficient to determine whether knee pads inhibit or improve volleyball performance. Future studies are to be carried out to explore effects of specific knee pads in volleyball players, taking into account their wide use in volleyball.

\section{Conclusions}

Pointing to the majority of volleyball players who use knee pads, this research was conducted with the aim of determining the effect of knee pads on important factors of volleyball performance. The conclusion is that wearing knee pads has neither an inhibitory nor a positive effect on the explosive power of the lower extremities; linear speed; and agility in young female volleyball players. However, to our knowledge, this is the first study that tried to examine the effects of knee pads in athletes and the first study that involved a specific population of volleyball players. Considering the importance of high level of these abilities for successful volleyball performance and at the same time the wide use of knee pads in volleyball players, further research in this area of is needed. This study provides data that will help coaches and volleyball players in resolving doubts about the use of knee pads for players of all ages, especially for young players whose locomotor system has not yet been formed. The findings of this study highlight that wearing knee pads do not deteriorate the physical performance of volleyball players and that their further use is desirable for the primary purpose, which is the prevention of potential knee injuries and consequences of frequent falls, which all together may have a positive impact on the psychological status and overall performance of the athlete. Moreover this study supports researchers who will try to examine and explain the impact of knee pads and to what extent they affect the prevention of potential knee injuries in volleyball players.

Author Contributions: Conceptualization, N.T., N.S. and M.B.; methodology, N.S.; software, S.A., and M.B.; validation, S.S., S.A. and N.S.; formal analysis, S.S., and M.B.; investigation, A.L.; resources, A.L.; data curation, S.A.; writing-original draft preparation, N.T.; writing-review and editing, A.L.; visualization, A.L.; supervision, N.T. All authors have read and agreed to the published version of the manuscript.

Funding: This research was funded by the Serbian Ministry of Education, Science and Technological Development.

Institutional Review Board Statement: The study was conducted according to the guidelines of the Declaration of Helsinki, and approved by the Novi Sad University Human Research Ethics Committee guidelines (ethical approval number: 20/2019).

Informed Consent Statement: Informed consent was obtained from all subjects involved in the study.

Conflicts of Interest: The authors declare no conflict of interest.

\section{References}

1. Voigt, H.; Vetter, K. The value of strength-diagnostic for the structure of jump training in volleyball. Eur. J. Sport Sci. 2003, 3, 1-10. [CrossRef]

2. Hasegawa, H.; Dziados, J.; Newton, R.U.; Fry, A.C.; Kraemer, W.J.; Häkkinen, K. Periodized training programmes for athletes. In Handbook of Sports Medicine and Science: Strength Training for Sport; Wiley Blackwell: Hoboken, NJ, USA, 2008.

3. Jastrzebski, Z.; Wnorowski, K.; Mikolajewski, R.; Jaskulska, E.; Radziminski, L.; Activity, P. The effect of a 6-week plyometric training on explosive power in volleyball players. Balt. J. Health Phys. Act. 2014, 6, 79. [CrossRef] 
4. Marques, M.C.; Van Den Tillaar, R.; Vescovi, J.D.; González-Badillo, J.; Research, C. Changes in strength and power performance in elite senior female professional volleyball players during the in-season: A case study. J. Strength Cond. Res. 2008, 22, $1147-1155$. [CrossRef] [PubMed]

5. Gabbett, T.; Georgieff, B.; Research, C. Physiological and anthropometric characteristics of Australian junior national, state, and novice volleyball players. J. Strength Cond. Res. 2007, 21, 902-908. [PubMed]

6. Sheppard, J.M.; Gabbett, T.J.; Stanganelli, L.-C.R.; Research, C. An analysis of playing positions in elite men's volleyball: Considerations for competition demands and physiologic characteristics. J. Strength Cond. Res. 2009, 23, 1858-1866. [CrossRef] [PubMed]

7. Marques, M.; González-Badillo, J.; Kluka, D.; Journal, C. In-season strength training male professional volleyball athletes. Strength Cond. J. 2006, 28, 2-12.

8. Grgantov, Z.; Milić, M.; Katić, R. Identification af explosive power factors as predictors of player quality in young female volleyball players. Coll. Antropol. 2013, 37, 61-68.

9. Skazalski, C.; Whiteley, R.; Bahr, R. High jump demands in professional volleyball-Large variability exists between players and player positions. Scand. J. Med. Sci. Sports 2018, 28, 2293-2298. [CrossRef]

10. Kim, Y.-Y.; Park, S.-E. Comparison of whole-body vibration exercise and plyometric exercise to improve isokinetic muscular strength, jumping performance and balance of female volleyball players. J. Phys. Ther. Sci. 2016, 28, 3140-3144. [CrossRef]

11. Trajković, N.; Krističević, T.; Baić, M. Effects of plyometric training on sport-specific tests in female volleyball players. Age 2016, $17,20-24$.

12. Lidor, R.; Ziv, G.; Research, C. Physical and physiological attributes of female volleyball players-A review. J. Strength Cond. Res. 2010, 24, 1963-1973. [CrossRef]

13. Johnson, T.M.; Brown, L.E.; Coburn, J.W.; Judelson, D.A.; Khamoui, A.V.; Tran, T.T.; Uribe, B.P.; Research, C. Effect of four different starting stances on sprint time in collegiate volleyball players. J. Strength Cond. Res. 2010, 24, 2641-2646. [CrossRef]

14. Zahradnik, D.; Jandacka, D.; Farana, R.; Uchytil, J.; Hamill, J. Identification of types of landings after blocking in volleyball associated with risk of ACL injury. Eur. J. Sport Sci. 2017, 17, 241-248. [CrossRef] [PubMed]

15. Lobietti, R.; Coleman, S.; Pizzichillo, E.; Merni, F. Landing techniques in volleyball. J. Sports Sci. 2010, 28, 1469-1476. [CrossRef]

16. Leporace, G.; Praxedes, J.; Pereira, G.R.; Pinto, S.M.; Chagas, D.; Metsavaht, L.; Chame, F.; Batista, L.A. Influence of a preventive training program on lower limb kinematics and vertical jump height of male volleyball athletes. Phys. Ther. Sport 2013, 14, 35-43. [CrossRef] [PubMed]

17. Tillman, M.D.; Hass, C.J.; Brunt, D.; Bennett, G. Jumping and landing techniques in elite women's volleyball. J. Sports Sci. Med. 2004, 3, 30. [PubMed]

18. Hughes, G.; Watkins, J.; Owen, N. The effects of opposition and gender on knee kinematics and ground reaction force during landing from volleyball block jumps. Res. Q. Exerc. Sport 2010, 81, 384-391. [CrossRef]

19. Gouttebarge, V.; van Sluis, M.; Verhagen, E.; Zwerver, J. The prevention of musculoskeletal injuries in volleyball: The systematic development of an intervention and its feasibility. Inj. Epidemiol. 2017, 4, 25. [CrossRef]

20. Rishiraj, N.; Taunton, J.E.; Lloyd-Smith, R.; Woollard, R.; Regan, W.; Clement, D.B. The potential role of prophylactic/functional knee bracing in preventing knee ligament injury. Sports Med. 2009, 39, 937-960. [CrossRef]

21. Pietrosimone, B.G.; Grindstaff, T.L.; Linens, S.W.; Uczekaj, E.; Hertel, J. A systematic review of prophylactic braces in the prevention of knee ligament injuries in collegiate football players. J. Athl. Train. 2008, 43, 409-415. [CrossRef]

22. Sitler, M.; Ryan, C.J.; Hopkinson, L.W.; Wheeler, L.J.; Santomier, J.; Kolb, L.R.; Polley, C.D. The efficacy of a prophylactic knee brace to reduce knee injuries in football: A prospective, randomized study at West Point. Am. J. Sports Med. 1990, 18, 310-315. [CrossRef]

23. Van Tiggelen, D.; Witvrouw, E.; Roget, P.; Cambier, D.; Danneels, L.; Verdonk, R. Effect of bracing on the prevention of anterior knee pain-A prospective randomized study. Knee Surg. Sports Traumatol. Arthrosc. 2004, 12, 434-439. [CrossRef]

24. Fleming, B.C.; Renstrom, P.A.; Beynnon, B.D.; Engstrom, B.; Peura, G. The influence of functional knee bracing on the anterior cruciate ligament strain biomechanics in weightbearing and nonweightbearing knees. Am. J. Sports Med. 2000, 28, 815-824. [CrossRef]

25. Deppen, R.J.; Landfried, M.; Therapy, S.P. Efficacy of prophylactic knee bracing in high school football players. J. Orthop. Sports Phys. Ther. 1994, 20, 243-246. [CrossRef] [PubMed]

26. Grace, T.G.; Skipper, B.; Newberry, J.; Nelson, M.; Sweetser, E.; Rothman, M.L. Prophylactic knee braces and injury to the lower extremity. J. Bone Jt. Surg. 1988, 70, 422-427. [CrossRef]

27. Risberg, M.; Beynnon, B.; Peura, G.; Uh, B.S. Proprioception after anterior cruciate ligament reconstruction with and without bracing. Knee Surg. Sports Traumatol. Arthrosc. 1999, 7, 303-309. [CrossRef]

28. Rovere, G.D.; Clarke, T.J.; Yates, C.S.; Burley, K. Retrospective comparison of taping and ankle stabilizers in preventing ankle injuries. Am. J. Sports Med. 1988, 16, 228-233. [CrossRef]

29. Rovere, G.D.; Haupt, H.A.; Yates, C.S. Prophylactic knee bracing in college football. Am. J. Sports Med. 1987, 15, 111-116. [CrossRef]

30. Baltaci, G.; Aktas, G.; Camci, E.; Oksuz, S.; Yildiz, S.; Kalaycioglu, T. The effect of prophylactic knee bracing on performance: Balance, proprioception, coordination, and muscular power. Knee Surg. Sports Traumatol. Arthrosc. 2011, 19, 1722-1728. [CrossRef] [PubMed] 
31. McDevitt, E.R.; Taylor, D.C.; Miller, M.D.; Gerber, J.P.; Ziemke, G.; Hinkin, D.; Uhorchak, J.M.; Arciero, R.A.; St. Pierre, P. Functional bracing after anterior cruciate ligament reconstruction: A prospective, randomized, multicenter study. Am. J. Sports Med. 2004, 32, 1887-1892. [CrossRef]

32. Najibi, S.; Albright, J.P. The use of knee braces, part 1: Prophylactic knee braces in contact sports. Am. J. Sports Med. 2005, 33, 602-611. [CrossRef]

33. Risberg, M.A.; Holm, I.; Steen, H.; Eriksson, J.; Ekeland, A. The effect of knee bracing after anterior cruciate ligament reconstruction. Am. J. Sports Med. 1999, 27, 76-83. [CrossRef]

34. Cook, F.F.; Tibone, J.E.; Redfern, F.C. A dynamic analysis of a functional brace for anterior cruciate ligament insufficiency. Am. J. Sports Med. 1989, 17, 519-524. [CrossRef]

35. Rebel, M.; Paessler, H. The effect of knee brace on coordination and neuronal leg muscle control: An early postoperative functional study in anterior cruciate ligament reconstructed patients. Knee Surg. Sports Traumatol. Arthrosc. 2001, 9, 272-281. [CrossRef]

36. Wu, G.K.; Ng, G.Y.; Mak, A.F. Effects of knee bracing on the functional performance of patients with anterior cruciate ligament reconstruction. Arch. Phys. Med. Rehabil. 2001, 82, 282-285. [CrossRef]

37. Mortaza, N.; Osman, N.A.; Jamshidi, A.A.; Razjouyan, J. Influence of functional knee bracing on the isokinetic and functional tests of anterior cruciate ligament deficient patients. PLOS ONE 2013, 8, e64308. [CrossRef] [PubMed]

38. Tegner, Y.; Lysholm, J.; Surgery, R. Derotation brace and knee function in patients with anterior cruciate ligament tears. Arthrosc. J. Arthrosc. Relat. Surg. 1985, 1, 264-267. [CrossRef]

39. Veldhuizen, J.; Koene, F.; Oostvogel, H.; Thiel, T.P.H.; Verstappen, F.J.I. The effects of a supportive knee brace on leg performance in healthy subjects. Int. J. Sports Med. 1991, 12, 577-580. [CrossRef] [PubMed]

40. Sforzo, G.A.; Chen, N.; Gold, C.A.; Frye, P.A. The effect of prophylactic knee bracing on performance. Med. Sci. Sports Exerc. 1989, 21, 254-257. [CrossRef]

41. Mortaza, N.; Ebrahimi, I.; Jamshidi, A.A.; Abdollah, V.; Kamali, M.; Abas, W.A.B.W.; Abu Osman, N.A. The effects of a prophylactic knee brace and two neoprene knee sleeves on the performance of healthy athletes: A crossover randomized controlled trial. PLoS ONE 2012, 7, e50110. [CrossRef] [PubMed]

42. Glatthorn, J.F.; Gouge, S.; Nussbaumer, S.; Stauffacher, S.; Impellizzeri, F.M.; Maffiuletti, N.A. Validity and reliability of Optojump photoelectric cells for estimating vertical jump height. J. Strength Cond. Res. 2011, 25, 556-560. [CrossRef]

43. Yeadon, M.; Kato, T.; Kerwin, D. Measuring running speed using photocells. J. Sports Sci. 1999, 17, 249-257. [CrossRef]

44. Sassi, R.H.; Dardouri, W.; Yahmed, M.H.; Gmada, N.; Mahfoudhi, M.E.; Gharbi, Z. Relative and absolute reliability of a modified agility T-test and its relationship with vertical jump and straight sprint. J. Strength Cond. Res. 2009, 23, 1644-1651. [CrossRef]

45. Triplett, N. Speed and Agility; Human Kinetics: Champaign, IL, USA, 2012; pp. 253-274.

46. Stewart, P.F.; Turner, A.N.; Miller, S.C. Reliability, factorial validity, and interrelationships of five commonly used change of direction speed tests. Scand. J. Med. Sci. Sports 2014, 24, 500-506. [CrossRef]

47. Cohen, J. Statistical Power Analysis for the Behavioral Sciences; Academic Press: Cambridge, MA, USA, 2013.

48. Dickerson, L.C.; Peebles, A.T.; Moskal, J.T.; Miller, T.K.; Queen, R.M. Physical performance improves with time and a functional knee brace in Athletes after ACL reconstruction. Orthop. J. Sports Med. 2020, 8, 8. [CrossRef] [PubMed]

49. Moon, J.; Kim, H.; Lee, J.; Panday, S.B. Effect of wearing a knee brace or sleeve on the knee joint and anterior cruciate ligament force during drop jumps: A clinical intervention study. Knee 2018, 25, 1009-1015. [CrossRef] [PubMed]

50. Rishiraj, N.; Taunton, J.E.; Lloyd-Smith, R.; Regan, W.; Niven, B.; Woollard, R. Effect of functional knee brace use on acceleration, agility, leg power and speed performance in healthy athletes. Br. J. Sports Med. 2011, 45, 1230-1237. [CrossRef] [PubMed]

51. Aktas, G.; Baltaci, G. Does kinesiotaping increase knee muscles strength and functional performance? Isokinet. Exerc. Sci. 2011, 19, 149-155. [CrossRef]

52. Kruger, T.H.; Coetsee, M.F.; Davies, S.E. The effect of Prophylactic knee bracing on selected performance patameters. Afr. J. Phys. Act. Health Sci. 2003, 9, 40-57. [CrossRef]

53. Borsa, P.A.; Lephart, S.M.; Fu, F.H. Muscular and functional performance characteristics of individuals wearing prophylactic knee braces. J. Athl. Train. 1993, 28, 336.

54. Albright, J.P.; Saterbak, A.; Stokes, J. Use of knee braces in sport. Sports Med. 1995, 20, 281-301. [CrossRef]

55. Greene, D.L.; Hamson, K.R.; Bay, R.C.; Bryce, C.D. Effects of protective knee bracing on speed and agility. Am. J. Sports Med. 2000, 28, 453-459. [CrossRef] [PubMed]

56. Mann, R.A.; Moran, G.T.; Dougherty, S.E. Comparative electromyography of the lower extremity in jogging, running, and sprinting. Am. J. Sports Med. 1986, 14, 501-510. [CrossRef]

57. Stephens, D.L. The effects of functional knee braces on speed in collegiate basketball players. J. Orthop. Sports Phys. Ther. 1995, 22, 259-262. [CrossRef] [PubMed]

58. Peña, J.; Moreno-Doutres, D.; Coma, J.; Cook, M.; Buscà, B. Anthropometric and fitness profile of high-level basketball, handball and volleyball players. Rev. Andal. Med. Deport. 2018, 11, 30-35. [CrossRef]

59. Bodendorfer, B.M.; Arnold, N.R.; Shu, H.T.; Leary, E.V.; Cook, J.L.; Gray, A.D.; Guess, T.M.; Sherman, S.L. Do neoprene sleeves and prophylactic knee braces affect neuromuscular control and cutting agility? Phys. Ther. Sport 2019, 39, 23-31. [CrossRef]

60. Rishiraj, N.; Taunton, J.; Clement, D.; Lloyd-Smith, R.; Regan, W.; Woollard, R. The role of functional knee bracing in a dynamic setting. N. Z. J. Sports Med. 2000, 28, 54-61. [CrossRef] 